\title{
A note on cytogenetic monitoring of geese in native conservative flocks*
}

\author{
R. Parada ${ }^{1,3}$, J. Książkiewicz ${ }^{2}$ and K. Jaszczak ${ }^{1}$ \\ ${ }^{1}$ Institute of Genetics and Animal Breeding, Polish Academy of Sciences \\ Jastrzębiec, 05-552 Wólka Kossowska, Poland \\ ${ }^{2}$ National Research Institute of Animal Production \\ 32-083 Balice, Poland
}

(Received 13 October 2010; revised version 26 April 2011; accepted 18 June 2011)

\begin{abstract}
The studies conducted aimed at evaluating the frequency of chromosome abnormalities in early embryos of 8 breeds/varieties of geese originating from the Southern and Northern parts of Poland, since the seventies of the XX century, without selection, avoiding interrelations.

In total 1927 eggs were evaluated, of which 485 were not fertile. The karyotypic survey was performed on 1442 embryos and showed that 65 of them (4.5\%) had an abnormal karyotype. Among the chromosome abnormalities the principal were: 1AZ haploidy; haploid-diploid chimerism 1AZ/2AZZ, 1AZ/2AZW; mosaic 2AZZ/3AZZZ. One embryo proved to be a pure tetraploid 4A/ ZZZZ. The translocation or inversion type of structural chromosome abnormalities were not observed.

A considerable variability was observed in the frequency of chromosome abnormalities between the geese varieties examined: from $2.99 \%$ in the Pomeranian variety to $7.58 \%$ in the case of the Hunched Breed. In the remaining six breeds/varieties the per cent of karyotype changes ranged from 3.38 to 4.73 .
\end{abstract}

KEY WORDS: embryos, chromosome abnormalities, conservative flock, geese

\footnotetext{
Supported by the State Committee for Scientific Research, Grant No. N311 013233

${ }^{3}$ Corresponding author: e-mail: R.Parada@ighz.pl
} 


\section{INTRODUCTION}

Reserve and conservative geese flocks constitute a unique material for investigations and render possible the evaluation of breeds and varieties already not used for commercial production but included in conservation programmes. Small, isolated populations, such as reserve and conservative geese flocks, must be genetically controlled, as in such closed populations there is a risk of an increased frequency of chromosome aberrations and a decreased genetic variability. This could lead, among much else, to an inbreeding depression, i.e. decreased production and lowered resistance to diseases.

The conservation of endangered species refers not only to wild living animals, but also to breeds, lines and varieties of farm animals, created by humans. Among the numerous reasons for protecting endangered species one may find economic, biological, scientific and cultural (Crawford, 1990; Wężyk et al., 1994; CywaBenko et al., 2006).

The level of spontaneous chromosome aberrations in different poultry species changes depending on breed, line, family and selection type (Reddy and Siegel, 1977; Snyder et al., 1979). Karyotype changes are responsible, among much else, for an increased embryo mortality during incubation and a lower hatchability. This makes cytogenetic surveys, determining the level of chromosome aberrations in poultry, especially advisable in conservative flocks.

The examinations performed aimed at evaluating the frequency of chromosome aberrations in early embryos of 8 breeds/lines of geese, originating from the Southern and Northern parts of Poland and maintained at the Institute of Animal Production, Department of Breeding Water Fowl, Dworzyska, since the seventies of the XX century, without selection, avoiding interrelations. Biological traits of geese from conservative flocks: resistance to illness, good quality of eggs (thick, strong shell), high reproductivity, longevity, adaptability to environmental conditions and ability to use less valuable feeds (Książkiewicz, 2007). The majority of native goose flocks have been included in the world's genetic resources (World Watch List for Domestic Animal Diversity; Scherf, 2000).

\section{MATERIAL AND METHODS}

The experimental material for the karyotype survey of early (48 h) geese embryos was collected during two subsequent laying periods and comprised a 100 eggs per breed/line: Lubelska (Lu), Kielecka (Ki), Sub-Carpathian (SC), Hunched Beak (HB), Kartuska (Ka), Rypinska (Ry), Suwalska (Su) and Pomeranian (Po). The size of flocks ranged from 45 to 55 males and from 135 to 156 females at 
2-3 years of age (Książkiewicz, 2007). Eggs were collected in April for tree days, pedigreed and stored at $12^{\circ} \mathrm{C}$ for two weeks and them placed in an incubator at $38^{\circ} \mathrm{C}$. After $48 \mathrm{~h}$ incubation the eggs were opened and examined macroscopically. The blastodisks from fertile eggs were removed and a cell suspension was made from each in a $2 \mathrm{ml}$ culture medium with an addition of colchicine. Further processing with short culture $(2 \mathrm{~h})$, hypotonic, fixation and slide preparation followed the method described by Zartman and Jaszczak (1979).

Fifty to one hundred metaphase spreads were analysed by scoring the presence of the largest 10 pairs of autosomes and sex chromosomes ZZ and ZW. The chisquare test (proc FREQ in SAS, 1999) was used to compare groups of embryos with regard to the incidence of embryos with chromosome abnormalities.

\section{RESULTS AND DISCUSSION}

In total 1927 eggs were examined (Table 1), of which 485 were not fertile. The karyotype survey covered 1442 embryos.

Table 1. The number of evaluated and not fertile goose embryos

\begin{tabular}{lccc}
\hline \multirow{2}{*}{ Variety } & \multirow{2}{*}{ Number of eggs examined } & \multicolumn{2}{c}{ Not fertile eggs } \\
\cline { 3 - 4 } & 234 & number & $\%$ \\
\hline Lubelska & 214 & 57 & 24.3 \\
Kielecka & 232 & 38 & 17.7 \\
Sub-Carpathian & 272 & 59 & 25.4 \\
Hunched Beak & 259 & 48 & 17.6 \\
Kartuska & 222 & 82 & 31.6 \\
Rypinska & 252 & 53 & 23.8 \\
Suwalska & 242 & 73 & 28.9 \\
Pomeranian & 1927 & 75 & 30.9 \\
Total & & 485 & 25.1 \\
\hline
\end{tabular}

The frequency of chromosome aberrations was determined for 1442 goose embryos. The karyotype survey showed 65 (4.5\%) embryos with an abnormal karyotype. Among the chromosome abnormalities the principal were: haploidy 1AZ; haploid-diploid chimerism 1AZ/2AZZ, 1AZ/2AZW; mosaics $2 \mathrm{AZZ} / 3 \mathrm{AZZZ}$ and, in the case of one embryo, a pure tetraploid $4 \mathrm{~A} / \mathrm{ZZZZ}$ (Table 2).

The translocation or inversion type of structural chromosome aberrations was not observed. Similarly as in other poultry species, they are rarely found. A clear majority of this type of irregularities are induced by X rays or chemical mutagens (Wooster et al., 1977). 
Haploidy $1 \mathrm{AZ}$ was the dominant chromosome aberration as it was observed in 32 embryos (2.21\%). The second was the haploid-diploid chimerism $1 \mathrm{AZ} / 2 \mathrm{AZZ}, 1 \mathrm{AZ} / 2 \mathrm{AZW}$ and the last the mosaic $2 \mathrm{AZZ} / 3 \mathrm{AZZZ}$. The haploidy, similarly as monosomy, is a lethal condition. Embryos that are $1 \mathrm{AZ}$ haploids are found only in the early stages of embryo development. Studies on the origin of haploidy, performed using gametes with a chromosome marker, have demonstrated that it may be of an androgenic origin. Haploidy cell lines in embryos and chicks being haploidy/poliploidy chimerism/mosaics 1A/2A; $1 \mathrm{~A} / 2 \mathrm{~A} / 3 \mathrm{~A}$ are of a similar origin (Fechheimer and Jaap, 1978). In turn, the

Table 2. Number and per cent of embryos with chromosome aberrations in conservative flocks of geese

\begin{tabular}{|c|c|c|c|c|}
\hline \multirow[b]{2}{*}{ Variety } & \multirow{2}{*}{$\begin{array}{c}\text { Number of embryos } \\
\text { examined }\end{array}$} & \multirow{2}{*}{$\begin{array}{c}\text { Chromosome aberrations } \\
\text { number }\end{array}$} & \multicolumn{2}{|c|}{ Aberrations } \\
\hline & & & number & $\%$ \\
\hline \multirow{4}{*}{ Lubelska } & \multirow{4}{*}{177} & $1 \mathrm{AZ}(4)$ & \multirow{4}{*}{8} & \multirow{4}{*}{4.51} \\
\hline & & $1 \mathrm{AZ} / 2 \mathrm{AZZ}(2)$ & & \\
\hline & & 1AZ/2AZW (2) & & \\
\hline & & $1 \mathrm{AZ}(4)$ & & \\
\hline \multirow{4}{*}{ Kielecka } & \multirow{3}{*}{176} & $1 \mathrm{AZW} / 1 \mathrm{AZ}$ & \multirow{4}{*}{7} & \multirow{4}{*}{3.97} \\
\hline & & $1 \mathrm{AZ} / 2 \mathrm{AZZ}$ & & \\
\hline & & $2 \mathrm{AZZ} / 3 \mathrm{AZZZ}$ & & \\
\hline & \multirow{4}{*}{173} & $1 \mathrm{AZ}(3)$ & & \\
\hline \multirow[t]{3}{*}{ Sub-Carpathian } & & $1 \mathrm{AZ} / 2 \mathrm{AZZ}(2)$ & \multirow[t]{3}{*}{6} & \multirow[t]{3}{*}{3.46} \\
\hline & & $1 \mathrm{AZ} / 2 \mathrm{AZW}$ & & \\
\hline & & $1 \mathrm{AZ}(7)$ & & \\
\hline \multirow{3}{*}{ Hunched Beak } & \multirow{3}{*}{224} & 1AZ/2AZZ (3) & \multirow{4}{*}{17} & \multirow{3}{*}{$7.58^{1}$} \\
\hline & & 2AZW/ZZ (5) & & \\
\hline & & 2AZZ/3AZZZZ (2) & & \\
\hline \multirow{7}{*}{ Kartuska } & \multirow{7}{*}{177} & $1 \mathrm{AZ}$ & & \multirow{6}{*}{3.38} \\
\hline & & $1 \mathrm{AZ} / 2 \mathrm{AZZ}$ & \multirow{6}{*}{6} & \\
\hline & & $2 \mathrm{AZZ} / \mathrm{ZW}$ & & \\
\hline & & $2 \mathrm{AZZ} / 4 \mathrm{AZZ}$ & & \\
\hline & & $2 \mathrm{AZZ} / 2 \mathrm{AZ}$ & & \\
\hline & & 4AZZZZ & & \\
\hline & & $1 \mathrm{AZ}(5)$ & & \\
\hline \multirow[t]{3}{*}{ Rypinska } & \multirow[t]{3}{*}{169} & $1 \mathrm{AZ} / 2 \mathrm{AZZ}(2)$ & \multirow[t]{3}{*}{8} & \multirow[t]{3}{*}{4.73} \\
\hline & & $2 \mathrm{AZZ} / \mathrm{ZW}$ & & \\
\hline & & $1 \mathrm{AZ}(6)$ & & \\
\hline \multirow{3}{*}{ Suwalska } & \multirow[t]{2}{*}{179} & $1 \mathrm{AZ} / 2 \mathrm{AZZ}$ & 8 & 4.46 \\
\hline & & $2 \mathrm{AZW} / \mathrm{ZZ}$ & & \\
\hline & & $1 \mathrm{AZ}(2)$ & & \\
\hline Pomeranian & 167 & $1 \mathrm{AZ} / 2 \mathrm{AZZ}$ & 5 & $299^{*}$ \\
\hline & 101 & $1 \mathrm{AZ} / 2 \mathrm{AZW}$ & 5 & 2.99 \\
\hline & & 2AZW/ZZ & & \\
\hline Total & 1442 & & 65 & 4.50 \\
\hline
\end{tabular}


diploid/triploid mosaics $(2 \mathrm{~A} / 3 \mathrm{~A})$ appears as result of disturbances in cytokinase during the initial divisions of embryo cells (Reddy et al., 1977)

The overall frequency of chromosome aberrations identified at the level of $4.5 \%$ in the embryos of 8 varieties and breeds of geese, maintained in conservation flocks, is comparatively low, when compared with the results reported by other authors. Jaszczak et al. (1999), performing a cytogenetic survey of 411 embryos of the Zatorska goose, maintained in a conservation flock and 486 embryos of the White Italian goose from a commercial flock, observed chromosome irregularities in 6.3 and $5.4 \%$ of cases, respectively. In other poultry species the same type of aberrations occur, on a similar or higher level than that observed in geese. Cytogenetic examinations of turkey embryos, representing two commercial lines - medium heavy (Nicholas 300) and heavy (Nicholas 700) - demonstrated 10.5\% of embryos with chromosomal aberrations (Jaszczak et al., 2003).

A considerable variability was observed in the frequency of chromosome aberrations between the goose varieties examined: from $2.99 \%$ for the Pomeranian variety to $7.58 \%$ for the Hunched Beak variety (difference significant at $\mathrm{P}<0.05$ ). In the remaining six varieties the per cent of karyotype irregularities ranged from 3.38 to 4.73 . A high level of chromosome abnormalities is responsible for the higher embryo mortality during incubation and a lower hatchability (Jaszczak and Jaszczak, 1993).

One should emphasise that the overall number of chromosome abnormalities in different bird species is certainly higher, as routine investigations as a rule cover 5-10 pairs of macrochromosomes. As the estimation and identification of the remaining pairs of microsomes is difficult, the information about the actually occurring abnormalities is in fact incomplete.

\section{REFERENCES}

Crawford R.D., 1990. Poultry genetic resources: evaluation, diversity and conservation. In: Poultry Breeding and Genetics. Elsevier, New York, pp. 43-60

Cywa-Benko K., Wężyk S., 2006. In situ conservation of laying hen genetic resources in Poland. World Poultry. Sci. J. 62, Suppl., 204-205

De la Sena C.A., Fechheimer N.S., Nestor K.E., 1992. Evidence for genetic etiology of heteroploidy in embryos of the Japanese quail (Coturnix coturnix japonica). Cytogenet. Cell Genet. 60, 140 145

Fechheimer N.S., Isakova G.K., Belyaev D.K., 1983. Mechanisms involved In the spontaneous occurence of diploid-triploid chimerism in the mink (Mustela visio) and chicken (Gallus domesticus). Cytogenet. Cell Genet. 35, 238-243

Fechheimer N.S., Jaap R.G., 1978. The parental source of heteroploidy in chick embryos determined with chromosomally marked gamets. J. Reprod. Fertil. 52, 141-146 
Jaszczak K., Jaszczak J., 1993. Chromosomal abnormalities in early embryos and commercial chick and hatchability in reproduction flock of layer and broiler hens. Genet. Pol. 34, 287-293

Jaszczak K., Parada R., Sacharczuk M., 2003. A note on chromosome abnormalities in early turkey embryos. J. Anim. Feed Sci. 12, 835-839

Jaszczak K., Rabsztyn A., Jaszczak J., Kapkowska E., 1999. A karyotypic survey of early goose embryos. Anim. Sci. Pap. Rep. 17, 67-72

Książkiewicz J., 2007. Historical background to create conservative flocks of geese in the possession of the Institute of Animal Production (in Polish). PIB Wiad. Zoot. XLV (3), 77-81

Reddy P.R.K., Siegel B.B., 1997. Chromosomal abnormalities in chickens selected for high and low body weight. J. Hered. 68, 253-256

SAS, 1999. SAS/STAT software Release 8.2. SAS Institute Inc. Cary, NC

Scherf B.D., 2000. World Watch List for Domestic Animal Diversity. $3^{\text {rd }}$ Edition. FAO, Roma

Synder M.D., Fechheimer N.S., Jaap R.G., 1979. Incidence and origin of heteroploidy, especially haploidy, in chick embryos from intraline and interline matings. Cytogenet. Cell Genet. 14, $63-75$

Wężyk S., Cywa-Benko K., Romanov M.N., 1994. Protection against the extinction of the native breeds of poultry in the countries of Eastern Europe. In: Proceedings of International Symposium: Work on Preserving Rare Breeds of Farm Animals. Balice (Poland), pp. 25-26

Wooster W.E., Fechheimer N.S., Jaap R.G., 1977. Structural rearrangements of chromosome in the domestic chicken: experimental production by X-irradiation of spermatozoa. Can. J. Genet. Cytol. 19, 437-446

Zartman D., Jaszczak K., 1979. A procedure for chromosome preparation from early chick embryos (in Polish). Prace Mat. Zoot. 23, 115-118 